\title{
TRATAMENTO DA MORDIDA CRUZADA ANTERIOR COM APARELHO ORTODÔNTICO REMOVÍVEL
}

Wagner Leandro OLIVEIRA, Alexandre MORO

A mordida cruzada anterior dentária, na fase da dentição mista, destacase nos exames de rotina de clínicos gerais, odontopediatras e fonoaudiólogos. Do ponto de vista da oclusão, cabe ao clínico geral a identificação, o diagnóstico e até mesmo a interceptação desta má oclusão, embora, sempre que possível, devam estar sob orientação de um ortodontista. Através de revisão de literatura e com o relato de um caso clinico, este trabalho visa verificar as características e a eficácia de um aparelho removível com mola digital, bem como o seu uso no tratamento de uma mordida cruzada anterior dentária, a qual se apresenta como resultado da má posição dos incisivos superiores. As molas digitais são amplamente utilizadas na ortodontia, e neste estudo observou-se sua efetividade no tratamento, com uma rápida e positiva resposta. Proporcionando uma melhora na função, na estética e auto-estima do paciente.

Palavras-chave: Má Oclusão; Aparelhos Ortodônticos Removíveis; Ortodontia. 